\title{
Güvenilir Haber Almada Uydudan Uzaktan Algılamanın Kullanımı
}

\section{Using Satellite Remote Sensing in Collecting Reliable News}

\author{
Engin Çağlak, ${ }^{a^{*}}$ Emre Özelkan ${ }^{\mathrm{b}}$ \\ ${ }^{a}$ Dr. Öğr. Üyesi, Çanakkale Onsekiz Mart Üniversitesi, İletişim Fakültesi, Gazetecilik Bölümü, Çanakkale/Türkiye. \\ ORCID: 0000-0002-9477-9435 \\ b Dr. Öğr. Üyesi, Çanakkale Onsekiz Mart Üniversitesi, Mimarlık ve Tasarım Fakültesi, Şehir ve Bölge Planlama Bölümü, Çanakkale/Türkiye. \\ ORCID: 0000-0002-2031-1610
}

\section{MAKALE BİLGİSI}

Makale Geçmişi:

Başvuru tarihi: 18 Ağustos 2018

Düzeltme tarihi: 29 Kasım 2018

Kabul tarihi: 04 Ocak 2019

\section{Anahtar Kelimeler:}

Haber,

Gazetecilik,

Uydu Teknolojileri,

Uzaktan Algılama,

Güvenilir Haber Alma.

\section{ART ICLEINFO}

\section{Article history:}

Received 18 August 2018

Received in revised form 29 November 2018

Accepted 04 January 2019

\section{Keywords:}

News,

Journalism,

Satellite Technologies,

Remote Sensing,

Reliable News Acquisition

\section{ÖZ}

Habercilikte doğru veriyi güvenilir kaynaktan almak esastır. Veri eksikliğinin olduğu bir ortamda yapılan haberin öğeleri de eksiktir. Kitle iletişim araçlarının, istenmeyen etkilerini önlemek veya doğru bilgiye hızlı ve somut bir şekilde ulaşmak gazetecilik açısından büyük önem taşımaktadır. Bu bağlamda uydu teknolojileri bilgi toplamak için en güvenilir araçlardan biridir. Bu çalışmada uydudan uzaktan algılamanın habercilik açısından sağladığı avantajlar geçmişte yaşanan olaylardan örneklerle anlatılmış ve habercilik açısından önemi araştırılmıştır. Çalışmanın evreni geçmişte yaşanmış ve yayınlamış örnek haber incelemeleri ve uydu görüntüleri üzerinden saha çalışmalarıdır. $\mathrm{Bu}$ çalışmanın sonucunda, zamanla yarışan habercilik sektöründe, uydu teknolojilerinin haber toplama teknikleri açısından doğru ve hızlı kullanımının gerekliliği ortaya konmaktadır. Aynı zamanda bilinçli veya bilinçsiz olarak yapılan dezenformasyona karşın uydudan uzaktan algılama teknolojisinin önemi vurgulanmaktadır.

\begin{abstract}
A B S T R ACT
In journalism, receiving the correct data from a reliable source is essential. In an environment where there is a lack of data, the news items are also missing. Achieving the right and concrete information and accordingly taking measures against damages that may arise later and are of great importance for journalism. In this context, satellite technology is one of the most reliable tools of gathering information. In this study, in terms of journalism, the advantages of satellite remote sensing were explained with examples from past events and the importance of satellite technology was investigated. The work's universe is sample news lived and published on the web and field studies through satellite images. As a result, the study reveals how satellite technology can be used accurately and quickly in terms of news gathering techniques. Additionally, this study emphasized the advantages of satellite remote sensing technology against conscious or unconscious information distortions.
\end{abstract}

\section{Giriş}

İnsanoğlunun tarihi sürekli bir gelişim ve değişim üzerine kuruludur. Son yüzyıla ismini veren iletişim teknolojilerindeki gelişmeler de insanları hem birey hem de toplumsal açıdan etkilemekte ve etkileri hala devam etmektedir. Özellikle Web 2.0'dan sonra bireyin hem üretici hem de tüketici olduğu dijital dünya hızla sanayi 4.0’a doğru evrimleşmektedir. Bilişim ve iletişim teknolojilerindeki bu gelişmeler, McLuhan'ın dediği gibi dünyayı daha da küresel bir köy haline getirmiş hatta avcumuzun içine sığdırmayı başarmıştır (Altay, 2003:17). Bilgi bombardımanının yoğun olarak yaşandığı bu teknoloji alanı doğal olarak habercileri ve haber toplama yöntemlerini de etkilemektedir. Profesyonel haberciliğin doğduğu ilk yıllarda olayları yerinde izlemek ve haber toplamak için aylarca seyahat eden

\footnotetext{
* Sorumlu yazar/Corresponding author

e-posta: ecaglak@comu.edu.tr
} 
gazeteciler, şimdi teknolojinin bütün nimetlerinden faydalanmaktadır. Anında görüntü paylaşabilmekte veya dünyanın bir ucundan görüntülü haber sunabilmektedir. Bununla birlikte çok sıcak gelişmelerin olduğu haberin kaynağından doğru ve hızlı haber toplama teknikleri olarak uydu teknolojileri ve uzaktan algilama teknikleri kullanılmaktadır.

\subsection{Haber}

Haber veya bir başka deyişle bilgi tarih boyunca çok önemli olmuştur. Bununla birlikte "Haber"in tanımı pek o kadar kolay olmamıştır. Özellikle haber nedir? Sorusuna ve daha sonra da haberci kimdir? Sorusuna çeşitli bakış açıları ve yorumları bulunmaktadır. Haber kavramının temel özelliklerini belirtmek için iki ana etkenden bahsedilmektedir. Birincisi toplum tarafından kabul görmüş ve kullanılan iletişim teknolojisi, ikincisi ise var olan toplumsal yapıdır. (Tokgöz, 2006:204) Toplumun genelini ilgilendiren Doğru, Tarafsız, İlginç, Yeni, Önemli ve Anlaşılır olması gereken haberin temel öğeleri, haberin tanımını daha mümkün kılmaktadır. Haber, yalın haliyle gerçekleri iletmektir. Mümkün olduğunca $5 \mathrm{~N} 1 \mathrm{~K}$ sorularına yanıt vermelidir (Schlapp, 2002:21). İngilizce haber kelimesi "news", North (Kuzey), East (Doğu), West (Bat1), South (Güney) kelimelerinin baş harflerinden üretilmiştir ki her yönde meydana gelen olayları ifade etmektedir. (Uyguç ve Genç, 1998:107) Haber kavramının yüzlerce tanımı ve açıklaması bulunmaktadır. Bununla birlikte haber özünde, bireyi yaşamsal anlamda ilgilendiren olaylar ve bu olaylarla ilgili bilgilerdir. (Girgin, 2002:3) Milattan önce eski mısırda daha sonraları haber olarak yorumlanabilecek bazı bilgilerin toplanıp derlendikten sonra resmi bir gazete gibi yayınlandığı bilinmektedir (Gülnar, 2016:2). Sezar Roma'sında ise ActaDiurna'lardan bahsedilmektedir (İnuğur, 1994:38). Coğrafi keşiflerle birlikte özellikle Avrupa anakarasında bilgiye yani habere ihtiyaç çok artmıştır. İlk kez 14. Yüzyıl sonlarında, bazı bilgi ve düşüncelerin elle yazılarak satılan haber mektupları, Venedik'te görülmektedir (Yenituna, 2016:96). Haberin hızla ve güvenilir bir şekilde dünyanın dört bir yanına yayılması ise 19. yüzyılda telgrafla mümkün olmuştur. Profesyonel anlamda haber servisi yine telgrafin yayılması ve haber ajansların kurulmasıyla mümkün olmuştur. Haber artık günlük olarak tüketilen bir meta halini almıştır (Wolf ve Josef, 2002:13).

Haber "olay" olarak ifade edilmektedir ve olay ise belli bir yer ve zaman içinde geçme süreci olarak tanımlamaktadır (Girgin, 2008: 113). Bununla birlikte "Olay"1 ortaya çıkan bir durum, sıra dışı olmasıyla toplumun ilgisini çeken "olgu" olarak açıklamaktadır. Bunlara ek olarak "olay”, söylem veya eylem olabileceği gibi her ikisini de içinde barındırabilmekte demektedir (Girgin, 2008: 103). Diğer taraftan haberin içeriğini inceleyerek farklı bir bakış açısıyla haberi tanımlayan Van Dijk, haberi bir türden daha çok söylem olarak incelemekte ve haber söyleminin, toplumun egemen söylemlerinin bir ürünü olarak ortaya çıktığını savunmaktadır. Öte taraftan bakacak olursak yani toplumsal değil de bireysel açıdan, Haber, bireylerin zamansal ve mekânsal yakınlık çerçevesinde uzun veya kısa süreli bilgi bağlantıları olarak görülmektedir (Girgin, 2008: 113).

\subsection{Haber Kaynakları}

İktidar, kamuoyu bağlamında ideolojik razı sağladığı toplumda kitle iletişim araçlarını kendi hegemonyasını kurmak için kullanmaktadır (Çoban, 2009:137). Siyasal aktörler veya toplum için bilgi akışı ve haber ne kadar önemliyse haberin kaynağı da bir o kadar önemlidir. Haberin kaynağı, haberin doğruluğu ile doğru orantılıdır. Haberde kaynak, haberin inandırıcılığını sağlayan önemli bir etkendir (AA, 2018:31). Değişen dünya ve gelişen iletişim teknolojileri ile birlikte haber kaynakları da değişiklik göstermektedir. Profesyonel anlamda haberciliğin doğduğu ilk yıllarda haber mektupları ve denizcilerin limanlarda anlattıkları bilgiler tek haber kaynağı olarak görülmektedir. Yalan haberler ve hikâyeler, habercileri doğru haber elde etmek için zorlamış ve bunun sonucunda da haber ajanslarının ortaya çıktığı görülmektedir. Haber ajanslarının çalışmasıyla birlikte profesyonel habercilik, gazetecilerin sınır ötesi görevlendirilmelerine, savaş muhabirliği gibi haberciliğin uzmanlaşmasına ve yurt dişı irtibat ofislerinin açılmasına sebep olmuştur. Bütün bu neden sonuç ilişkilerinin temelinde ise bilgiyi bir başka deyişle haberi ilk elden, birincil veri kaynağı olarak kullanma isteği yatmaktadır. Bunun da genel sebebi doğru haber verebilme çabasıdır. (Topuz, 2003:79)

Gazetecilikte en önemli olan basamaklardan biri de haber toplamaktır. Bununla birlikte üzerine çalışılan haberin türüne göre de haber kaynakları farklılık gösterebilmektedir. Klasik anlamda gazetecilerin haber kaynaklarını birkaç başlıkta sıralamak mümkündür. Siyasi aktörler haber kaynaklarının başında yer almaktadır. Devlet başkanı, parti başkanı, belediye başkanı, valilik, meclis üyesi, resmi kurum ve kuruluşlar, sendikalar, Kolluk kuvvetleri polis veya jandarma, silahlı kuvvetler ve komutanları, sanayi ve ticaret odaları, sanat ve eğlence işletmeleri, eğitim kurumları ve özel sektöre ait kuruluşlar haberin kaynağı olarak görünmektedir. Diğer taraftan resmi veya özel ayrımı olmaksızın haber kaynaklarının temelinde kurum ve kuruluşların özelinde insan birinci derecede haber kaynağıdır (Tokgöz, 2006:235-250).

Kitle iletişim araçları açısından haber kaynakları, iç kaynaklar ve diş kaynaklar olarak ikiye ayrılmaktadır. İç kaynaklar, gazete veya basın kuruluşlarının kendi istihbarat kadroları, bölge muhabirleri, haber başına ücret alan muhabirler, haber ajanslarının bültenleri, diğer basın kuruluşlarının yayınları, takip edilen basın toplantıları, diğer kuruluşların basın bültenleri olarak sıralamak mümkündür. Dış kaynaklar ise, ajansların dış haber bütenleri, dış ülkelerdeki muhabir ya da temsilciler, yabancı ajans, gazete, radyo ve televizyon yayınları, büyükelçilikler, yabancı temsilcilikler ve uluslararası kuruluşların haber bültenleridir. (Girgin, 2002:21)

Çağımızın iletişim çağı olarak adlandırılmasıyla birlikte haber kaynakları da özünde insanı korumakta bununla birlikte kullanılan araçlar ve kanallar değişiklik göstermektedir. Gazetelerin birincil haber kaynakları Haber Ajansları, Basın Bültenleri, Basın Toplantıları ve Muhabirin Özel Haber Araştırması gibi başlıklar altında toplanmaktadır. (Wolf ve Raue, age.) Diğer taraftan gazete çalışanı muhabir açısından bakacak olursak haber temel anlamda "Birinci el kaynaklar ve İkinci el kaynaklar" olarak iki kaynağa sahiptir. Genel anlamda ise dört başlık altında 
toplamak mümkündür. 1. Haber ajansları. 2. Birinci el haber kaynakları. Muhabirin kendisi yani tanıklık ettiği haberdir. 3. İkincil el haber kaynakları. Tanıktan edinilen bilgilerdir. 4. Üçüncü el haber kaynakları. Tanıktan dinleyenin aktardığı bir başka deyişle söylentidir. (Arsan, 2003:140)

Birinci el kaynaklarda muhabir olay veya olguya tanıklık eder, gözlemler, bilgi toplar ve aktarır. Yerinden Haber Toplama olarak isimlendirilen bu yöntemde gazeteci olaya bizzat tanıklık ederken, insanlarla mülakat, bilgi toplama yönteminde ise direkt olarak olaya tanıklık etmiş insanların gözlem ve şahitliklerini mülakat yoluyla öğrenir ve haber olarak aktarmaktadır. Bunlara ek olarak bir de ikinci el kaynaklar söz konusudur ki genel anlamda rapor, daha önceden yazılmış haber veya bilgi, ikinci ağızdan aktarım gibi kaynakları barındırmaktadır. Birincil veya ikincil el kaynakların en önemli ortak noktası ise doğru ve güvenilir bilgi içermesidir (Tokgöz, 2006:203). İletişim çağının getirdiği yenilikler ve olanaklar sonucunda internet ve sosyal medya, haberciler arasında önemli haber kaynaklarından biri olarak ilk sıralarda görülmektedir.

\subsection{Gelișen Teknoloji ve Değișen Habercilik}

Dünya tarihi boyunca pek çok buluş insanlık tarihinin gidişatında etkin olmuştur. İletişim teknolojilerinde yaşanan gelişmeler ise McLuhan'ın dediği gibi dünyayı daha da küçültmüș ve ulaşılabilir hale getirmiştir. Özellikle bilginin süratle ulaşması ve ulaşılabilir olması dünyaya çok hızlı şekil ve yön vermektedir. Haberin temel öğeleri değerlerini korumakla birlikte, İletişim teknolojileri, web 2.0 ve sanayi 4.0 süreci haberciliğin işleyişini ve haber toplama tekniklerini önemli ölçüde etkilemekte ve değiştirmektedir. Bu değişimin en net örneklerinden biri 1990 yılında patlak veren Körfez Krizi ve hemen ardından gelen 1991 Körfez Savaşı olarak gösterilebilir. Bütün dünya CNN üzerinden savaşı canlı izlemişti. Daha sonra 2001'de yaşanan İkiz Kule saldırıları da yine bütün dünya ile eş zamanlı olarak yayınlanmıştı (Tokgöz, 2006:67). Daha önce bahsi olan haber toplama yöntemleri ve kaynaklarına ek olarak internet, sosyal medya, sosyal uygulamalar ve benzeri mecralar yeni haber kaynakları olarak gözlemlenmektedir. İletişim teknolojisinin gelişimi ve iletişim kanallarının kullandığı araçlarda, haber toplama tekniklerine yenilerini katmaktadır. Özellikle cep telefonları ile yapılan haber kayıtları yeni bir kavramı ortaya çıkartmıştır, "Yurttaş Gazeteciliğì" (AA., 2018:200). Yurttaş Gazeteciliğinin öne çıan temel dayanaklardan biri de, haber yapım sürecinde, konuyla ilgili tüm haber kaynaklarına erişilmesi ve görüşlerine yer verilmesidir (Duran, 2005:95). Bununla birlikte Habere daha profesyonel gözle bakan ve haber toplayan gazeteciler de teknolojinin nimetlerinden faydalanmaktadır. Bunların en başında internet gelmekle birlikte birincil elden haber toplama yöntemi olarak, olaylara ve olgulara tanıklık etmek adına "Drone"lar, gazetecilerin yeni oyuncakları, yeni kameraları, yeni objektifleri veya bir başka deyişle gökyüzündeki gözleri konumundadır. Drone'lar anında yaşanan, sıcak haberlerin takibi için habercilere büyük kolaylıklar sağlamakta ancak çalışma alanı ve zamanı olarak kısıtlı imkânlar sunmaktadır. Ulaşılması daha zor, daha uzak mesafeler ve daha geniş bir zaman dilimi için ise yeni haber toplama kaynağı olarak uydular görülmektedir. Özellikle uyduların sivil kullanıma açılmasıyla birlikte "Uzaktan
Algılama" başlığı altında yeni haber toplama tekniği olarak gazetecilik literatürüne girmektedir.

\subsection{Uydu Teknolojileri ve Uzaktan Algilama}

Habercilikte doğru ve güvenilir bilgiye ulaşmak en önemli konudur. Yanlış bilginin yerel, ulusal ve uluslararası olumsuz etkileri ve sonuçları olabilir. Bu bağlamda olayı yerinde görüntülemek en doğru bilgiyi haber yapmaya olanak tanır. Uzaktan algılama nesnelere temas etmeksizin algılayıcılar ile bilgi toplama yöntemidir. Uzaktan algılama, belli bir uzaklıktan, ölçüm aletleri kullanarak, fiziksel temasta bulunmadan nesneler hakkında bilgi edinilmesidir (Url 1). İlk olarak balonlara, uçurtmalara ve hatta güvercinlere yerleştirilen kameralar ile gerçekleştirilen uzaktan algılama 19. Yüzyıl sonu ve 20. yüzyıl başı ile uçaklar ile gerçekleştirilmiştir (Tatar 2011:65). 1950'li yıllardan itibaren uydu görüntüleri çalışmaları başlamıştır, 1960'larda sağlıklı uydu görüntüleri elde edilse de 1972 yılında başarı ile çalışan Landsat 1 uydusu ile uydudan uzaktan algılama da dönüm noktası olmuştur (Url 1, Tatar 2011:66). Yaklaşık yarım yüzyıldır, uydu teknolojilerindeki hızlı gelişmeler dünyamızın çok daha ayrıntılı bir şekilde incelenmesine imkân tanımaktadır. Özellikle çözünürlüklerin (mekânsal, radyometrik, spektral ve zamansal) gelişmesi uydudan uzaktan algılamayı daha kullanışlı bir hale getirmiştir. Mekânsal çözünürlük uydu görüntüsünün bir pikselinin tanımladığı büyüklüktür ve kilometrelerden santimetreler seviyesine yükselmiştir (Url 2). Büyük ölçekte meydana gelen bir atmosfer olayını takip ederken $\mathrm{km}$ seviyesi yeterli olurken küçük bir nesnenin durumu, varlığı ve yokluğu üzerine yapılan bir araştırmada $\mathrm{cm}$ seviyesi büyük önem taşımaktadır. Radyometrik çözünürlükteki artış ile uydu görüntüsündeki bir pikselin ifade ettiği parlaklık değerinde (bit değeri) büyük artış elde edilmiştir (Rao vd. 2007:444). Diğer bir deyişle elektromanyetik enerjinin büyüklüğüne karşı duyarlılık nesnelerin renklerinin daha iyi ayırt edilebilmesine olanak tanır (Url 3). Spektral çözünürlük elektromanyetik spektrum üzerinde algılanan dalga boyu aralığı, büyüklüğü ve miktarıdır (Boyacı vd. 2015:135). Her nesnenin spektral imzası farklı olduğu için spektral çözünürlükteki artış nesnelerin özellikle kendi iç gruplarında daha iyi ayrıt edilebilmesine olanak tanımaktadır (Liu vd. 2018:2). Zamansal çözünürlük uydunun bir noktayı ne sıklıkla görüntülediğinin ölçüsüdür $\left(\begin{array}{lll} & \end{array}\right)$ Zrl Zamansal çözünürlükteki artış özellikle değişim belirleme ve inceleme konularında büyük kolaylık sağlamaktadır. Bununla beraber acil durum programlaması ile istenilen alanları görüntülemek için yönlendirilebilen askeri uyduların yanında sivil uydular da mevcuttur (Url 4).

Haberin niteliğine göre ihtiyaç olunan uydu ve çözünürlüğü de değişmektedir. Örneğin hızla değişebilen atmosfer olayları için düşük mekânsal çözünürlüklü ancak geniş alanları kapsayan yüksek spektral, radyometrik ve zamansal çözünürlüklü bir uydu görüntüsü tercih edilmesi beklenir (Url 5, Url 6). Ormancılık ve tarım gibi bitki çalışmalarında yüksek spektral, radyometrik ve çalışmanın ölçeğine göre yüksek ve en azından çalışma alanının ölçeğine göre orta mekânsal çözünürlüklü uydu görüntülerinin tercih edilmesi beklenir (Ozelkan vd. 2011:52, Waser 2014:4517, Ozelkan vd. 2016:162). Yine dinamik yapısından dolayı su ve sulak alan çalışmalarında ise gibi zamansal çözünürlüğün yüksek 
olmasının yanı sıra mekânsal ve spektral çözünürlüğün de yüksek olması tercih edilir (Karaman vd. 2015:75, Karaman vd. 2018:140, Özelkan ve Karaman 2018:2015). Şehircilik çalışmalarında ise yüksek mekânsal çözünürlüklü uydu görüntüleri tercih edilir (Chen vd. 2017:231).

\section{Yöntem ve Veri}

$\mathrm{Bu}$ çalışmada uydu görüntüleri kullanarak dünyamızı 3 boyutlu gösteren bir program olan Google Earth tarafindan ücretsiz sunulan yüksek çözünürlüklü multispektral uydu görüntüleri kullanılmıştır. Ek olarak Yunanistan'da gerçekleşen orman yangını için USGS (Birleşik Devletler Jeolojik Araştırmalar Kurumu) tarafından ücretsiz yayınlanan Landsat 8 OLI (Operational Land Manager) multispektral uydu görüntüleri kullanılmıştır. Görüntülerde görsel değerlendirmeler ile yorumlar yapılmıştır. Görüntülerde ilgili konunun öncesi sonrası şeklinde değerlendirmeler gerçekleştirilmiştir. $\mathrm{Bu}$ bağlamda kullanılan uydu görüntülerinin tarihleri ve görüntülenen bölgeler Tablo 1'de verilmiştir.

\section{Bulgular ve Tartışma}

Uydu teknolojileri ve uzaktan algilama teknikleri haberciler için çok yabancı bir konu olmasa da kullanım alanlarının dar ve kısitlı olduğu aşağıda incelenen haberlerde görülmektedir:

Özellikle uydu görüntülerinin yurtdışı kaynaklı ve dış haberler servisinin çalışmaları öne çıkmaktadır. Web üzerinde yayın yapan internethaber.com isimli sitede yer alan haberde, orman yangının büyüklüğünü vurgulamak için uydudan çekilen görüntülerden faydalanılmıştır. Haberde fotoğrafların NASA'dan alındığı ve bu görüntüler üzerine ekstra bir çalışma yapılmadığ 1 görülmektedir. Ne kadarlık bir alanın alevlerden etkilendiği veya yangın sonrası bir uydu görüntüsü paylaşılmamaktadır (Url 8). Terörist bir saldırının haberini takipçilerine aktaran Mynet.com adlı site, yine uydu görüntüleri ve "Google Earth" görüntülerini kullanılmıştır. Habere tanıklığın olmadığı bu görüntüler de daha çok harita amaçlı kullanılmaktadır (Url 9). Türkiye'nin en çok okunan gazetelerinden birisi olan Hürriyet Gazetesi aynı zamanda en çok ziyaret edilen internet haber sitelerinden biridir (Url 10). Web sitesinde yer alan 06.01.2017 tarihli haberde Antarktika'da dev bir cismin tespit edildiği aktarılmaktadır.

NASA'dan alınan uydu görüntüleri haberin ana konusunu oluşturmakta ama onun dışında herhangi bir araştırma veya görüntüleme çalışmasının haberde olmadığı sadece diş haberler servisinin tercüme ettiği bir haber niteliğindedir (Url 11). Hürriyet Gazetesinin resmî web sayfasında yer alan haberde ise dış haberler servisinin aktardığını ve uydu görüntülerinin kullanıldığı görülmektedir. Habere tanıklık etmekten çok uzak olan bu görüntülerin daha çok harita niteliği taşıdığı görülmektedir (Url 12). Bir internet sitesinde yer alan 26.05.2018 tarihli haberde ise doğal bir afet olan yanardağ patlamasının uzaydan nasıl göründüğü aktarılmaktadır (Url 13). Bir web sayfasında yer alan haberde ise Türkiye'nin Rasat uydusunun görüntüleri haber amaçlı kullanılmaktadır. "Trakya'da yaşanan selin etkileri RASAT Uydusu ile görüntülendi" başlıklı haberde yaşanan doğal afetin boyutları ve verdiği zararlar görülmektedir. Haberde afet öncesi (2014) ve sonrası (2015) olarak iki ayrı fotoğraf okuyucularla paylaşılmaktadır (Url 14).
Tablo 1. Tablo 1: Kullanılan uydu görüntüleri (12'nci ayın 1'ni gösteren görüntülerde belirtilmediğinden gün bilgisi 01 olarak eklenmiştir).

\begin{tabular}{|c|c|c|c|}
\hline Şekil No. & Bölge & Konu & Tarih \\
\hline Şekil 1 & Balıkesir - Bigadiç & Maden & 01.12 .1986 \\
\hline Şekil 1 & Balıkesir - Bigadiç & Maden & 01.12 .2016 \\
\hline Şekil 2 & Çanakkale - Çan & Maden & 01.12 .1984 \\
\hline Şekil 2 & Çanakkale - Çan & Maden & 01.12 .2016 \\
\hline Şekil 3 & İstanbul - Şile & Yapılaşma & 01.12 .1984 \\
\hline Şekil 3 & İstanbul - Şile & Yapılaşma & 01.12 .2016 \\
\hline Şekil 4 & Kocaeli - Merkez & Yapılaşma & 01.12 .1984 \\
\hline Şekil 4 & Kocaeli - Merkez & Yapılaşma & 01.12 .2016 \\
\hline Şekil 5 & İstanbul - Yenikapı & Kıyı şeridi & 12.04 .2013 \\
\hline Şekil 5 & İstanbul - Yenikapı & Kıyı şeridi & 13.12 .2017 \\
\hline Şekil 6 & İstanbul - Boğaz & Deniz Trafiği & 29.04 .2017 \\
\hline Şekil 7 & Burdur - Merkez & Kuraklık & 01.12 .1984 \\
\hline Şekil 7 & Burdur - Merkez & Kuraklık & 01.12 .2016 \\
\hline Şekil 8 & Çanakkale - Merkez & Orman Yangını & 19.03 .2014 \\
\hline Şekil 8 & Çanakkale - Merkez & Orman Yangını & 12.04 .2015 \\
\hline Şekil 9 & Yunanistan - Melissi, & Orman Yangını & 17.07 .2018 \\
\hline Şekil 9 & Yunanistan - Melissi, & Orman Yangını & 02.08 .2018 \\
\hline Şekil 10 & Şanlıurfa - Harran & Tarım & 27.05 .2017 \\
\hline Şekil 11 & Suriye - Palmira & Terör & 20.04 .2014 \\
\hline Şekil 11 & Suriye - Palmira & Terör & 03.12 .2016 \\
\hline Şekil 12 & Suriye - Rakka_1 & Terör & 02.02 .2015 \\
\hline Şekil 12 & Suriye - Rakka_1 & Terör & 07.01 .2017 \\
\hline Şekil 13 & Suriye - Rakka_2 & Terör & 02.13 .2013 \\
\hline Şekil 13 & Suriye - Rakka_2 & Terör & 02.02 .2015 \\
\hline Şekil 14 & Türkiye & Meteoroloji & 31.07 .2018 \\
\hline
\end{tabular}

$\mathrm{Bu}$ çalışmada elde edilen uzaktan algılama yöntemleriyle uydu görüntüleri incelenmiş ve bu bulgular çevre haberleri ve gündem haberleri açısından tartışılmaktadır. Şekil 1'de görüldüğü üzere Balıkesir ili sınırları içinde yer alan maden çalışmalarının yıllar içerisinde (1986-2016) yaklaşık altı katı kadar bir değişim olduğu görülmektedir. Özellikle çevre haberi açısından bakıldı ̆̆ büyüklüğü gözler önüne serilmektedir. Çevre haberlerine bir başka örnek Şekil 2'te, Çanakkale İli Çan İlçe' sinde faaliyet gösteren maden çalışma sahalarının ve buna bağlı gelişen sanayi bölgelerinin seksenli yıllarda yaklaşık 40 hektar civarında bir alanda yürütülürken şu anda yaklaşık 2000 hektarlık bir alana yayılarak devam etmesidir. Habercilerin uzun süre haber yaptığı ve uzun süre gündem olan İstanbul Anadolu yakası son ormanlarından geçen İstanbul Kuzey Otoyolu ve devam eden madencilik ve betonlaşma sorunları ile ilgili görseller Şekil 3'de görülmektedir. Çevrecilerin de kullandı $\breve{g}_{1}$ ve itirazların yapıldı $\breve{g}_{1}$ bu görsellerde çevresel tahribata yol ve maden çalışmalarının sebep olduğu görülmektedir.

Büyük illerde en çok yapılan haberlerden biri kentleşme sorunlarıdır. Habercilik açısından çevre haberleri ve toplumsal duyarlılık her zaman büyük önem arz etmektedir çünkü haberciler için birinci önceliklerden biri toplumsal faydadır. Google Earth'den elde edilen 1984 ve 2016 uydu görüntülerinde Kocaeli Körfezinde yaşanan kentleşmenin 
zamansal değișimi görülmektedir (Şekil 4). Diğer taraftan kentleşme dâhilinde inşa edilen köprüler ve otoyollar beraberinde getirdikleri ve götürdükleri de yine gözler önüne serilmektedir. Son yılların tartışılan gündem maddelerinden biri İstanbul'un büyük bir meydana sahip olmadığıdır. Büyük miting ve toplanma sahasının olmadığı İstanbul'da deniz yaklaşık 65 hektar doldurularak Yenikapı miting alanı oluşturulmuştur (Şekil 5). İstanbul Boğazı deniz trafiğinin en yoğun ve riskli olduğu bölgelerden biridir. Uydu görüntüleri ile deniz trafiği ve deniz kirliliği gibi konular sıklıkla çalışılmaktadır. Şekil 6'da ki uydu görüntüsü ile İstanbul Boğazı trafiğinin hareketli yapısı görülmektedir.
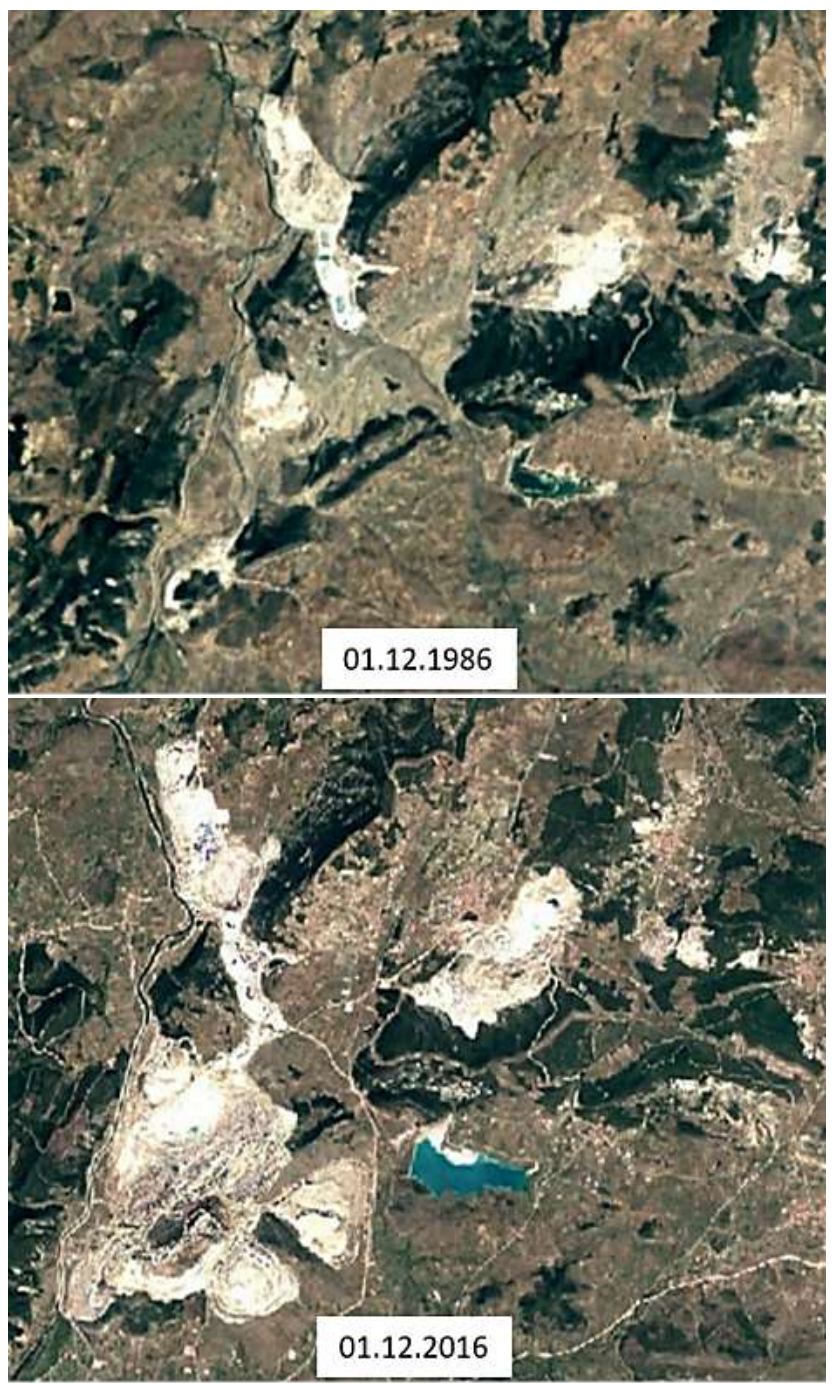

Şekil 1: Balıkesir ili maden alanlarındaki değişim

Habercilerin yakında takip ettikleri konu başlıklarından bir tanesi de doğal afetlerdir. Şekil 7'de Burdur Gölü'nde 1984'den 2016 yılına gelindiğinde oluşan değişim görülmektedir. Görüldüğü üzere yıllar içerisinde nasıl bir kuraklık yaşandığı ve suların \%30'dan fazla çekildiği yine uydu görüntüleri ile belgelenmektedir.

Orman yangınları özellikle sıcak iklim bölgelerinde sıkça görülen bir afet türüdür. Hem doğal hem de insani etkenlerden dolayı oluşabilir. Zararları ise maddi, manevi ve ekolojik olarak büyük etki yaratmaktadır. Bu kapsamda orman yangınlarının sebep olduğu anlık etkiler ve sonrasında oluşabilecek oluşumlar gazeteciler tarafindan takip edilmektedir. Çanakkale İli'nde 2014 yılında yaşanan orman yangınının öncesi, sonrası ve yanan yaklaşık 93 hektarlık alan Şekil 8'de görülmektedir. Şekil 9'da ise 24 Temmuz 2018'de 3 ayrı bölgede (Şekil 9‘da soldan sağa Melissi, Kineta ve Mati) yaklaşık 9000 hektar alanda etkili olan ve 92 kişinin hayatını kaybettiği orman yangının öncesi ve sonrası Landsat 8 OLI multispektral uydu görüntüleri ile gösterilmektedir (Url 15).

Tarım, ülke ekonomileri (enflasyon, istihdam vb.) için çok önemli bir sektördür. Tarımsal ürünlerin varlığı-yokluğu, ithalatı-ihracatı ulusal ve uluslararası politikaların önemli bir parçasıdır. Uydu görüntüleri ekilen tarım alanı, ürün miktarı, ürün tipi, tarımsal verim ve yıllık ürün toplamı gibi bilgileri edinmek adına haberciler kadar ilgili kurumların çalışmaları ve kontrolleri için de kullanılabilmektedir. Şekil 10'da Harran Ovası'ndaki tarım alanlarını gösteren uydu görüntüsü görülmektedir.

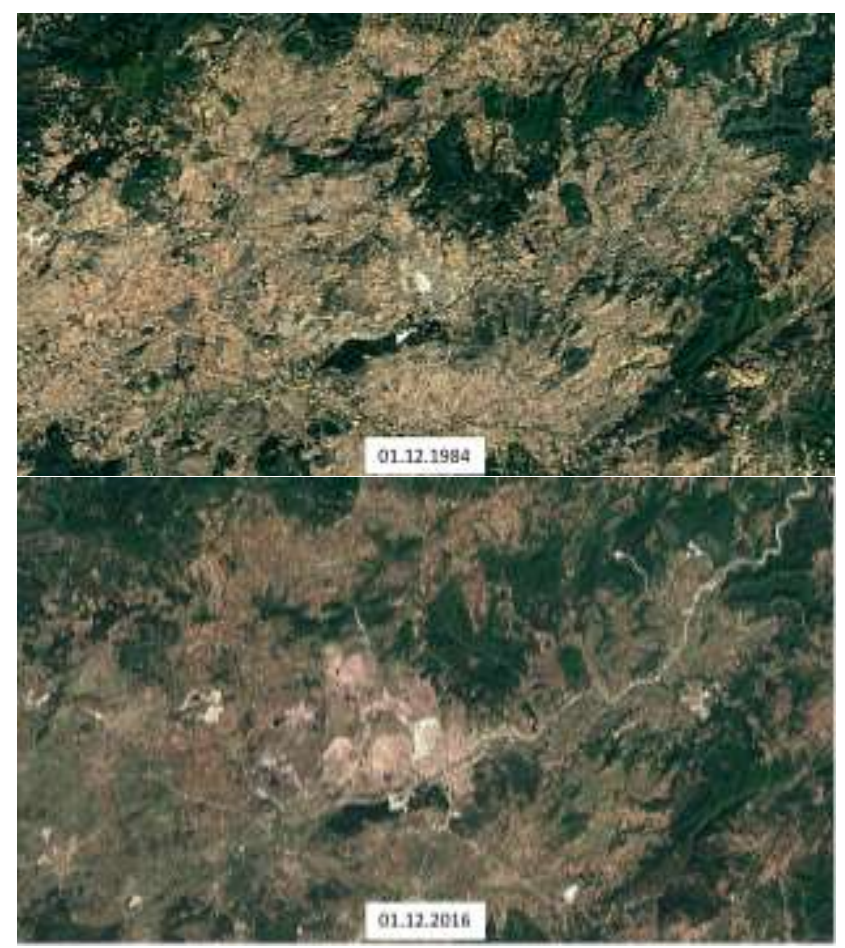

Şekil 2: Çan İlçe’ si maden ve sanayi bölgelerindeki değişim

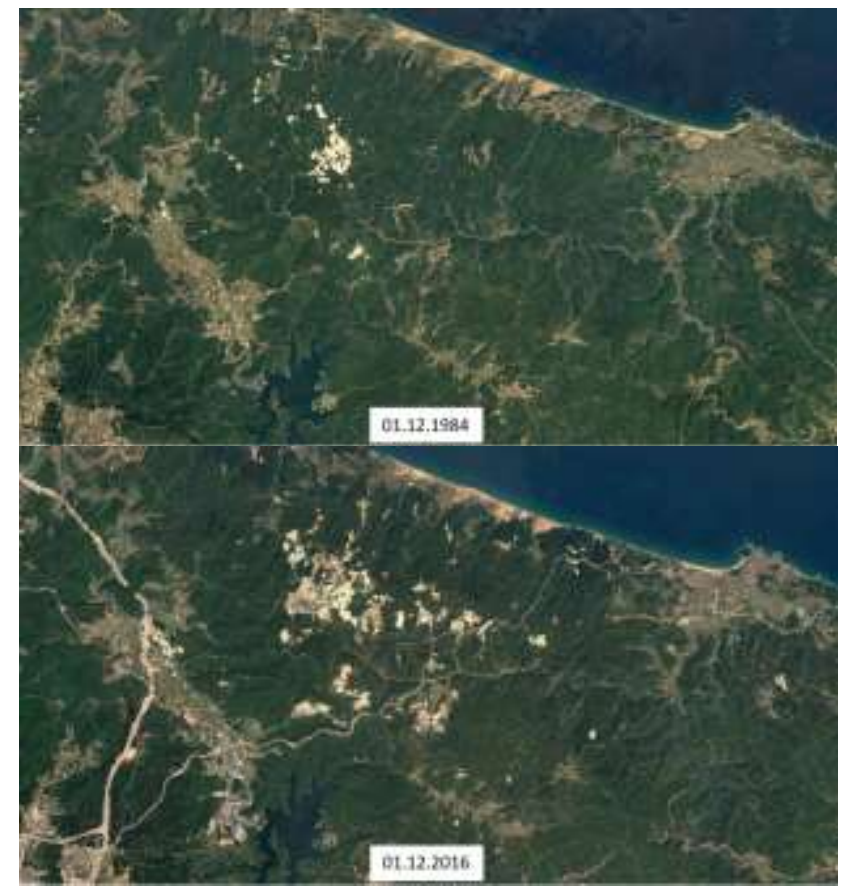

Şekil 3: İstanbul kentleşme, maden ve yol çalışmaları 



Şekil 4: Kocaeli Körfez bölgesi kentleşmenin zamansal gelişimi
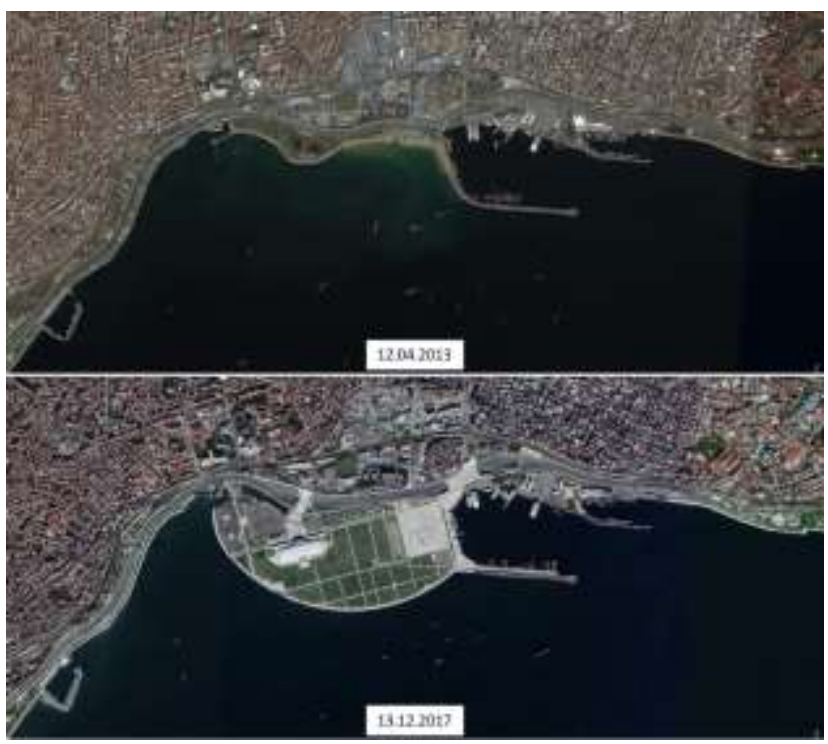

Şekil 1: İstanbul Yenikapı kıyı şeridi değişimi

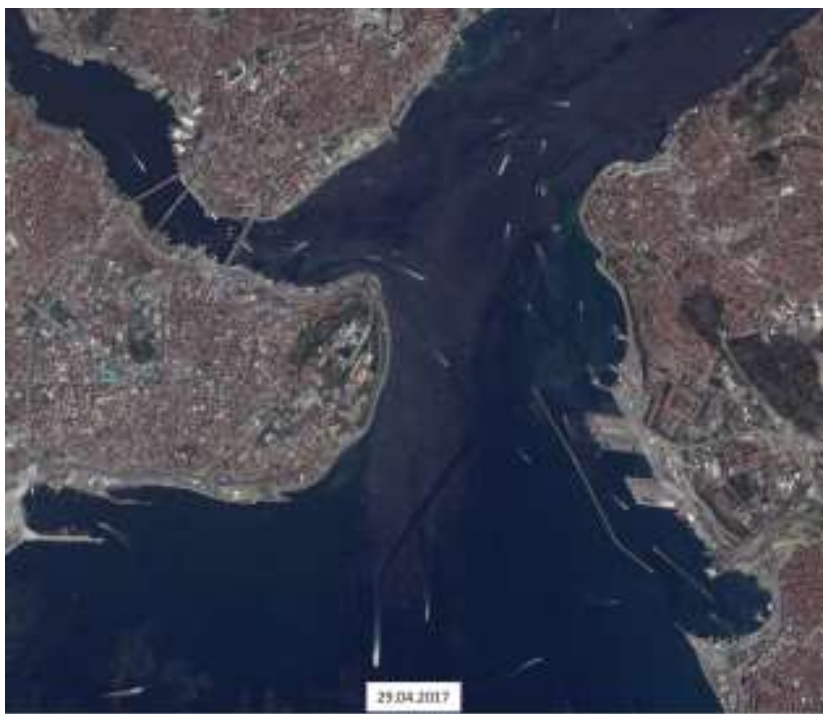

Şekil 2: İstanbul boğaz deniz trafiği

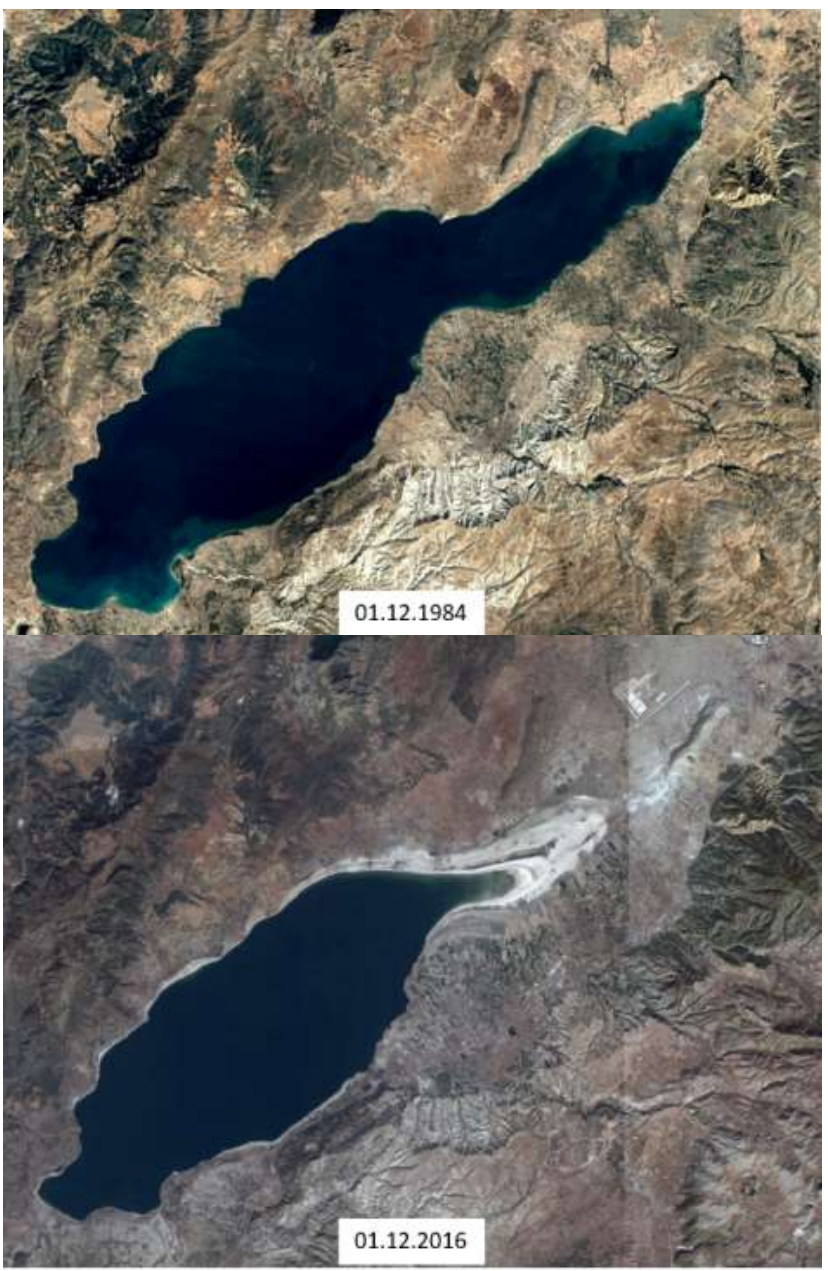

Şekil 7: Burdur Gölü’ndeki alansal değişim

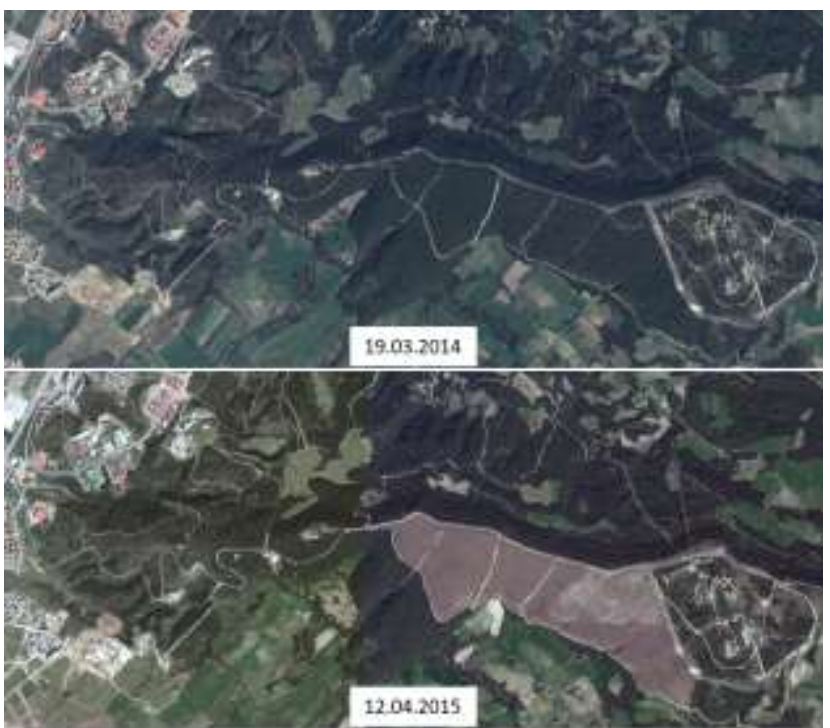

Şekil 8: Çanakkale orman yangınının öncesi ve sonrası

Özellikle savaş haberleri, haberciler ve gündem için çok önemli başlıklardan biridir. Burada ki görselde Suriye'de yaşanan iç savaşta DAEŞ'li teröristlerin tarihi Palmira kenti kalıntılara yapmış oldukları tahribatın öncesi ve sonrası görülmektedir (Şekil 11). Dünya kültürel mirasın korunması ve terörist grupların yapmış oldukları yıkımı yerinde tespit etmek habercilik açısından ne kadar zor olsa da uydudan uzaktan algılama ile yaşananları dünya kamuoyuyla paylaşmak habercilik açısından önemli bir görev olarak görülmelidir. 


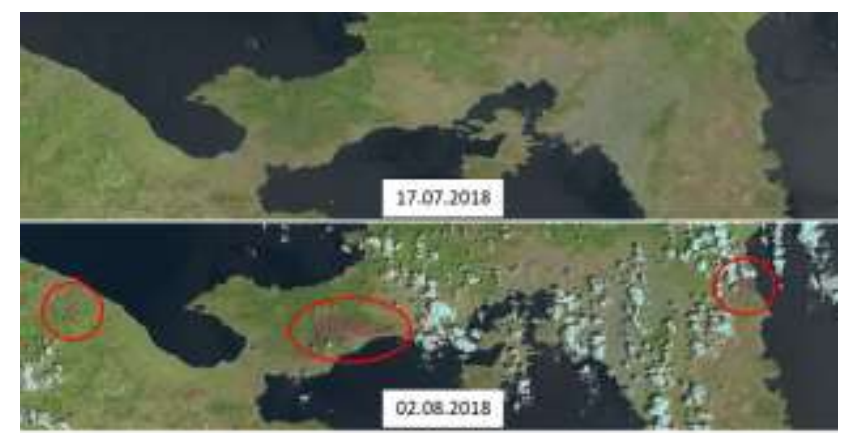

Şekil 9: Yunanistan orman yangınının öncesi ve sonras1

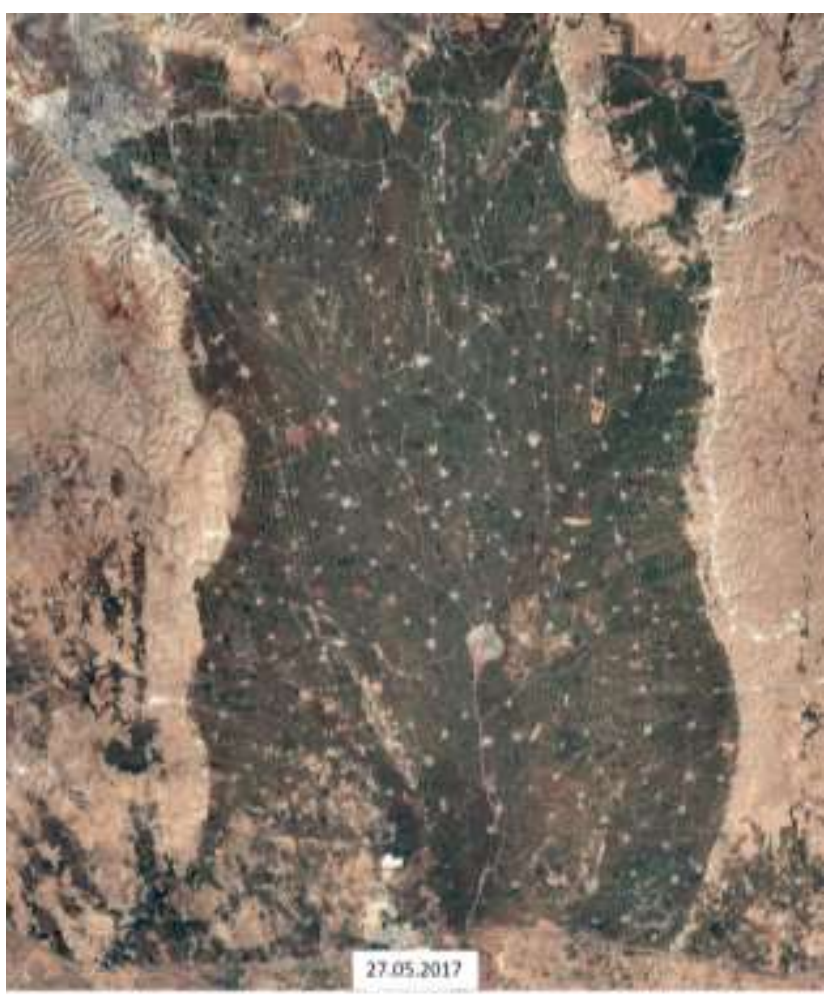

Şekil 10: Harran Ovası tarım alanları

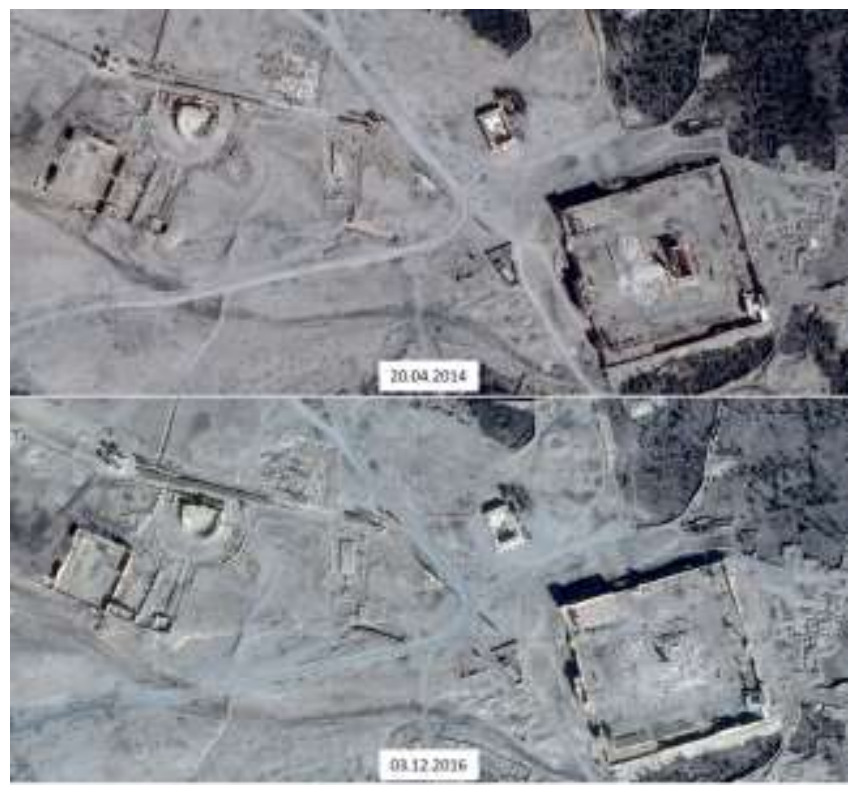

Şekil 11: Palmira antik kenti.

Gazetecileri Koruma Komitesi (CPJ) raporlarına göre sıcak çatışma bölgelerinde ve savaş alanlarında her yıl onlarca gazeteci haber toplarken yaşamını yitirmektedir (Url 16). Gazeteci sadece doğru olanı okuyucu-izleyici kitlesine aktarmak için çaba gösterirken hayatını kaybedebilmektedir. Aynı zamanda savaşın tarafları da kendi haklılıklarını ispat etmek için bilgi kirliliği yani dezenformasyon yapabilmektedir. Çatışma alanlarında bir taraf sivil hedefler vuruldu demekte karşı taraf ise askeri hedefler vuruldu demektedir. Bunun tespitinin ise yine uydudan görüntüleme sistemlerinin yardımıyla uzaktan algilama ile yapilabilmektedir. Şekil 12'de Rakka Tren İstasyonu ve çevresindeki tahribat görülmektedir. DAEŞ'li teröristler tarafinda Rakka şehrinde bulunan Veysel Karani Türbesinin nasıl yıkıldığı ve savaşın acı yüzü bir kez daha kendini göstermektedir (Şekil 13).

Meteoroloji bilgileri tarımdan hayvancılığa, kent yaşamından ulaşıma, spor müsabakalarından sağlığa kadar pek çok konuda büyük önem taşıdığından haberlerde önemli yere sahiptir. İstanbul gibi mega kentlerde, Trakya ve Karadeniz gibi sel bölgelerinde, Ege ve Akdeniz gibi yangın potansiyeli yüksek yerlerde ve Çukurova gibi tarım merkezlerinde meteoroloji haberleri daha da büyük ilgi ve alaka görmektedir. Uydu görüntüleri erken uyarı sistemleri için de önemli bir tipidir. Uydudan uzaktan algılama yöntemiyle toplanan bu veriler haberciler için vazgeçilmez haber kaynakları olarak öne çıkmaktadır (Şekil 14).



Şekil 12: Rakka tren istasyonu.
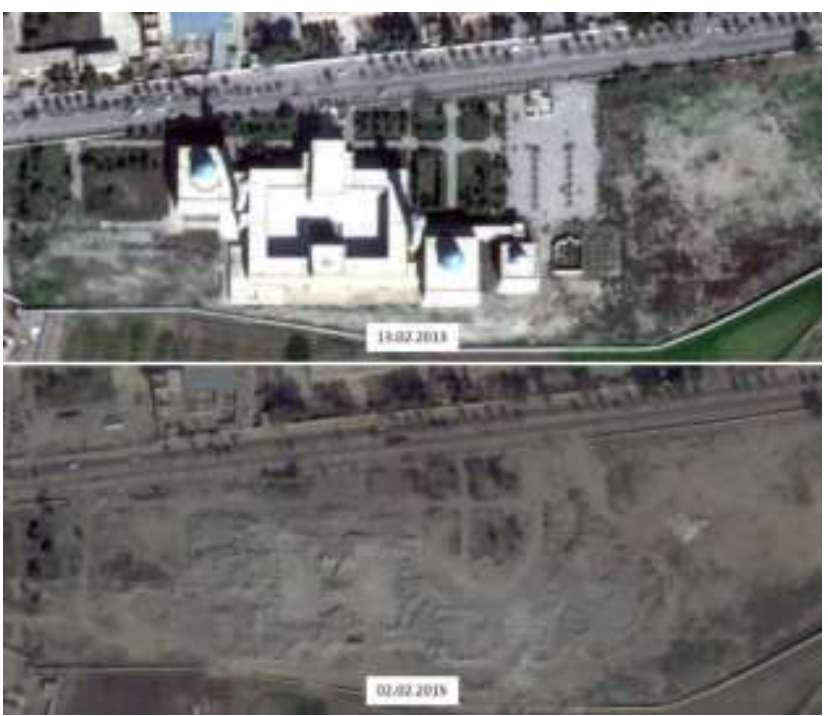

Şekil 13: Rakka Veysel Karani Türbesi 


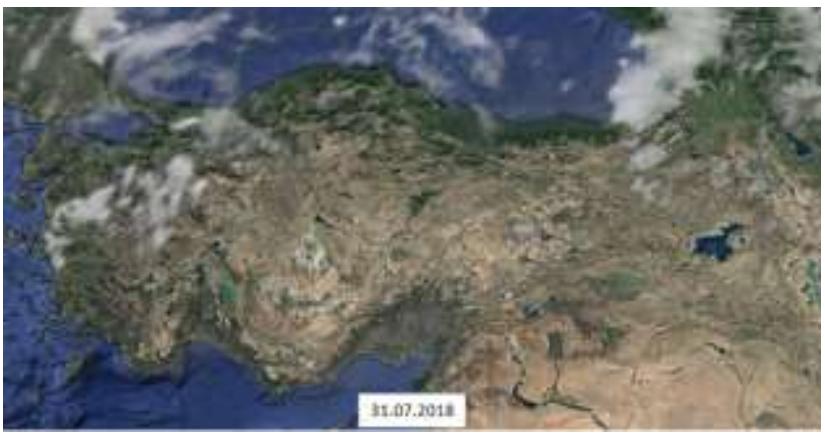

Şekil 3: Türkiye üzerindeki bulutların dağılımı

\section{Sonuç ve Öneriler}

Haberin kaynağı insan odaklı olmakla beraber, haber toplama teknikleri, teknolojik gelişmelerle birlikte değişkenlik göstermektedir. Uydudan uzaktan algılama şu anki ve öngörülen teknolojik imkanlar doğrultusunda çok yüksek çözünürlüklü (mekânsal, radyometrik, spektral ve zamansal) veri temin edebilme imkânı sağlamaktadır. Genel olarak yüksek mekânsal çözünürlüklü uzaktan algılama uyduları pek çok alan için gerekli olsa da maliyetleri nedeniyle bu verilere herkes kolaylıkla ulaşamamaktadır. Bu nedenle eğer bir sponsor yoksa çoğunlukla çalışmalar ücretsiz ancak düşük ya da orta çözünürlüklü uydu görüntüleriyle devam etmektedir. Türkiye son yıllarda uydu teknolojileri konusunda özellikle Göktürk ve Rasat uyduları ile önemli adımlar atmıştır ve atmaya devam etmektedir (Url 7). Uydu teknolojilerindeki gelişmeler ulusal güvenliğimiz sağlanması ve dışa bağımlılığımızın ortadan kalkması için son derece önemlidir. Bölgemizde ve çevre ülkelerde yaşanan sıcak olayların ve yaşanan çatışmaların pek çoğu propaganda malzemesi olarak kullanılmaktadır. Özellikle bu tür propagandalar ve itibarsızlaştırma çalışmalarına zamanında ve doğru bilgilerle cevap verebilmek adına haberciler, haberin kaynağına en hızlı ve sağlıklı ulaşabilmek için uydu teknolojileri ve uzaktan algılama verilerini kullanabilmelidir. Devlet haber organları için milli uydu görüntüsü arşivini kullanıma açabilir. Hatta olağanüstü ve gerekli durumlarda uydu geçişlerini doğru veriye ulaşmak adına yenide programlayabilir. Özellikle devletin ilgili organları Anadolu Ajansı ve diğer haber ajansları için Göktürk ve Rasat uyduları önemli haberlerde oluşabilecek bozulmaları engellemek adına kısıtlı da olsa erişime açılabilir.

Güvenilir ve doğru veriye ulaşmak toplumsal huzuru sağlar. Her türlü propaganda ve spekülasyonlara açık haberler, en kısa zamanda doğru dokümanlarla gerçekleri ortaya koyabilmek, gazetecilik görevi kadar toplumsal bir gerekliliktir. Halkı kışkırtmalar ve galeyana getirmeler azalır. Geçmişte yaşanan pek çok örneğinin olduğu 5-6 Eylül 1955 Güz Olayları veya yakın tarihte yaşanan Gezi Parkı Olayları sırasında maruz kaldığımız bilgi bombardımanları arasında doğru ve tarafsız olanı seçmek gazeteciler kadar toplum ve birey için de zor bir okuma olduğu görülmüştür. Yakın zamanda ise Türk Silahlı Kuvvetleri'nin yürüttüğü Afrin Operasyonu'nda, Afrin Hastanesi'nin vurulduğu ve çok sayıda sivilin hayatını kaybettiğine dair spekülasyon yaratacak yalan haberler yurtiçinde ve yurtdışında haber merkezleri tarafindan servis edilmiş ve Türkiye karşıtı propaganda malzemesi olarak kullanılmak istenmiştir. Bu tür spekülatif haberlerin daha baskıya veya yayına girmeden önünü kesilmesi ve profesyonel haberciler tarafindan yalanlanması en doğru habercilik olacaktır.

Sonuç olarak uydu teknolojileri ve uzaktan algılama, çalışılacak ve haber olacak konunun içeriğine göre farklı özelliklerde, güvenilir veri temin edebilecek bir seviyededir. Bu çalışmada mevcut imkânlar dâhilinde multispektral uydu görüntüleri kullanılmıştır. Bununla birlikte hızla gelişmekte olan hiperspektral ve RADAR (RAdio Decection And Ranging) uydu teknolojileri de araştırılan konuya göre zengin bilgi sunabilmektedir. Bu bilimsel ve teknolojik birikim gelişmiş ülkeler tarafından her alanda olduğu gibi habercilikte de sıklıkla kullanılmaktadır. Böylelikle gelişmiş ülkeler güvenilir ve hızlı haber alma konusunda büyük ilerleme kaydetmişlerdir. Hızlı ve güvenilir olması açısından bilişim ve iletişim teknolojileri ile sürekli gelişen uydudan uzaktan algilama teknolojileri günümüzde önemli bir araç olarak görülmektedir ve gelecekte güvenilir haber almada önemini daha da arttıracaktır.

\section{Kaynakça}

Altay, D. (2003). Kadife Karanlık. İçinde: Rigel, N. ve diğerleri (Der.), McLuhan (s. 9-48). 2. Bask1, İstanbul: Su Yayınları

Anadolu Ajansı (AA). (2018). Muhabir Habercinin Temel Kitabı. 2. Baskı, İstanbul: Anadolu Ajansı Yayınları

Arsan, E. (2003). Gazetecilik ve Habercilik. İçinde: Alankuş, S. (Der.), Haber ve Habercilik (s. 137-152). 2. Bask1. İstanbul: IPS İletişim Vakfi Yayınları.

Boyac1, D., M. Erdoğan, M. ve F. Yıldız., F. (2015). Çözünürlüğün Sınıflandırmaya Etkisi. TUFUAB VIII. Teknik Sempozyumu, 134-139. 21-23 Mayis 2015 / Konya.

Chen G., Özelkan E., Singh K.K. , Zhou J., Brown M.R., Meentemeyer M.R. (2017). "Uncertainties in mapping forest carbon in urban ecosystems", Journal of Environmental Management, vol.187, pp.229-238.

Çoban, B. (2009). Medya Eleştirileri Kitle İletişim ve Toplumsalın Üretimi. İçinde: Akbulut, N.T. ve Bilgili, C. (Der.), Medya, Kamuoyu, İdeoloji (s. 13-162). İstanbul: Beta Yayınları.

Duran, R. (2005). Gazetecilik ve Habercilik. İçinde:Alankuş, S. (Der.), Yurttaş Gazeteciliği (s. 91107). 2. Baskı İstanbul: BİA IPS İletişim Vakfı Yayınları

Girgin, A. (2002). Haber Yazmak. İstanbul: Der Yayınları.

Girgin, A. (2008). Gazeteciliğin Temel İlkeleri. İstanbul: Der Yayınları.

Gülnar, M. (2016). Bu Toprakların İletişim Tarihi. İçinde: Çağlak, E. (Ed.) Anadolu'da Yazının Tarihi (s. 1-14). İstanbul: Nobel Yayınevi

İnuğur, N. (1994). Basın ve Yayın Tarihi. İstanbul: Der Yayınları

Karaman, M., Budakoglu, M., Avcı, Z.D.U., Ozelkan, E., Bulbul, A., Civas, M., Ve Tasdelen, S. (2015). Determination of seasonal changes in wetlands using CHRIS/Proba Hyperspectral satellite images: A case 
study from Acigöl (Denizli), Turkey. Journal of environmental biology, 36(1), 73.

Karaman, M., Özelkan, E., Taşdelen, S. (2018). Dar Nehirlerin Sentinel2-A Uydu Görüntüleri ile Belirlenebilirliğinde Havza Hidrojeolojisinin Etkisi:Karamenderes (Çanakkale) Örneği. Doğal Afetler ve Çevre Dergisi, 4 (2), 140-155. DOI: 10.21324/dacd.416514

Liu, J., Luo, B., Douté, S., Chanussot, J. (2018). Exploration of Planetary Hyperspectral Images with Unsupervised Spectral Unmixing: A Case Study of Planet Mars. Remote Sens. 2018, 10, 737.

Özelkan E., Ormeci C., Karaman M. (2011). Determination of the Forest Fire Potential by Using Remote Sensing and Geographical Information System, Case StudyBodrum/Turkey. Proceedings of the 8th International EARSeL FF-SIG Workshop Stresa (Italy, Stresa, ITALYA, 20-21 Ekim 2011, pp.51-56

Ozelkan, E., Chen, G., Ustundag, B.B. (2016). "Multiscale object-based drought monitoring and comparison in rainfed and irrigated agriculture from Landsat 8 OLI imagery", Int. Journal of Applied Earth Observation and Geoinformation, 44, 159-170.

Özelkan, E., Karaman, M. (2018). Baraj Göllerindeki Meteorolojik Ve Hidrolojik Kuraklığın Etkisinin Çok Zamanlı Uydu Görüntüleri İle Analizi: Atikhisar Barajı (Çanakkale) Örneği. Ömer Halisdemir Üniversitesi Mühendislik Bilimleri Dergisi, 7 (2), 1023-1037. DOI: 10.28948/ngumuh.443230

Rao, N.R. Garg, P.K., Ghosh, S.K. (2007). Evaluation of radiometric resolution on land use/land cover mapping in an agricultural area, International Journal of Remote Sensing, 28:2, 443-450, DOI: $10.1080 / 01431160600733181$

Schlapp, H. (2002). Gazeteciliğe Giriş. Aygün Işık (Çev.). 2. Bask1, İstanbul: İstanbul Üniversitesi İletişim Fakültesi Yayınları

Tatar, Y. (2011). Uzaktan Algılama Tarihçesine Genel Bir Bakış. Biga Yarımadası'nın Jeolojisi Sempozyumu 6590. Aralık 2011

Waser, L.T., Küchler, M., Jütte, K., Stampfer, T. (2014). Evaluating the Potential of WorldView-2 Data to Classify Tree Species and Different Levels of Ash Mortality. Remote Sens. 6, 4515-4545.

Tokgöz, O. (2006). Temel Gazetecilik, 6. Bask1, İmge Kitapevi: Ankara

Topuz, H. (2003). II. Mahmuttan Holdinglere Türk Basın Tarihi, İstanbul: Remzi Kitabevi.

Uyguç, Ü. ve Genç A. (1998). Radyo Televizyon Haberciliği, İstanbul: Avcıol Basım-Yayın.

Van Djik, T. (1988). News as Discourse, New Jersey: Lawrence Erblaum.
Wolf, S. P. ve Josef, R. (2002). Gazetecinin El Kitabı. Aygün Işık, (Çev.). 2. Baskı, İstanbul: İst. Üni. İletişim Fakültesi Yayınları

Yenituna, B. (2016). Bu Toprakların İletişim Tarihi. İçinde: Çağlak, E. (Ed.) Sancılı Bir Doğum ve Gelişim Hikayesi; Türk Basını (s. 95-114). İstanbul: Nobel Yayınevi

Url

http://www.ktu.edu.tr/dosyalar/ormanamenajmani_3fc8 b.pdf (Erişim Tarihi, 6.7.2018)

Url 2: https://www.satimagingcorp.com/satellitesensors/geoeye-2/ (Erişim Tarihi, 9.7.2018)

Url

https://www.hvkk.tsk.tr/Havacilik_Kosesi/Ozel_Siteler/ Kesif_Uydu_Komutanligi/Genel_Bilgiler/Cozunurluk_ Degeri (Erişim Tarihi, 8.7.2018)

Url 4: http://www.intelligenceairbusds.com/files/pmedia/public/r457_9_satelliteprogra mming_uk_sept2010.pdf(Erişim Tarihi, 9.7.2018)

Url 5: https://earth.esa.int/web/eoportal/satellitemissions $/ \mathrm{m} / \mathrm{meteosat}-\mathrm{second}$-generation (Erişim Tarihi, 7.7.2018)

Url 6: https://modis.gsfc.nasa.gov/about/specifications.php (Erişim Tarihi, 6.7.2018)

Url 7: http://uzay.tubitak.gov.tr/tr/projeler/uydu (Erişim Tarihi, 8.7.2018)

Url 8: http://www.internethaber.com/orman-yanginlariuzaydan-bile-gorundu-nasanin-fotograflari-uzucu-fotogalerisi-1789930.htm (Erişim Tarihi, 10.7.2018)

Url 9: http://www.mynet.com/haber/guncel/iste-en-aciuydu-fotografi-597912-1 (Erişim Tarihi, 9.7.2018)

Url 10: http://www.medyatava.com/haber/turkiyenin-encok-ziyaret-edilen-haber-siteleri-aciklandi_150072 (Erişim Tarihi, 8.7.2018)

Url 11: http://www.hurriyet.com.tr/seyahat/galeri-nasauydulari-antarktikada-dev-bir-cisim-tespit-etti40324076\#page-1 (Erişim Tarihi, 11.7.2018)

Url 12: http://www.hurriyet.com.tr/dunya/abdden-esadrejimine-agir-suclama-mahkumlarin-cesetlerini-firindayaktilar-40459062 (Erişim Tarihi, 11.7.2018)

Url 13: http://www.webtekno.com/hawaii-de-yasananyanardag-patlamasi-uzaydan-nasil-gorunuyorh46795.html (Erişim Tarihi, 8.7.2018)

Url 14: http://blog.gezgin.gov.tr/?p=216 (Erişim Tarihi, 11.7.2018)

Url 15: http://tr.euronews.com/2018/07/31/yunanistanyanginlarda-kaybettiklerini-andi (Erişim Tarihi, 12.7.2018)

Url 16: https://www.amerikaninsesi.com/a/ikibinonaltiyilinda-kirksekiz-gazeteci-olduruldu/3642382.html (Erişim Tarihi, 8.7.2018) 

